\title{
Multitiered Health Assessment of Atlantic Menhaden in the Pamlico River, North Carolina
}

\author{
A. K. JOHNSON* \\ Department of Natural Sciences, University of Maryland Eastern Shore, \\ Princess Anne, Maryland 21853, USA \\ J. M. LAW \\ Department of Population Health and Pathobiology and Center for Comparative Medicine and Translational \\ Research, College of Veterinary Medicine, North Carolina State University, \\ 4700 Hillsborough Street, Raleigh, North Carolina 27606, USA \\ C. A. Harms \\ Environmental Medicine Consortium and Center for Marine Sciences and Technology, \\ Department of Clinical Sciences, College of Veterinary Medicine, North Carolina State University, \\ 303 College Circle, Morehead City, North Carolina 28557, USA \\ J. F. LEVINE \\ Department of Population Health and Pathobiology, College of Veterinary Medicine, \\ North Carolina State University, 4700 Hillsborough Street, Raleigh, North Carolina 27606, USA

\begin{abstract}
During the fall of 2001 and 2002, Atlantic menhaden Brevoortia tyrannus were collected from several creeks in the Pamlico River, North Carolina, to investigate recent fish kills and ulcerative skin lesions. High skin lesion prevalence $(>50 \%)$ was associated with the Atlantic menhaden kills in fall 2001, whereas there were no fish kills in fall 2002 and skin lesion prevalence was lower $(\leq 50 \%)$. Indicators of tissue damage (histopathological analyses of gills, heart, liver, intestine, and anterior kidney), body condition (liver somatic index), and immune status (transforming growth factor- $\beta$ [TGF- $\beta$ ] messenger RNA [mRNA] production, hematology, plasma chemistry, and splenosomatic index) were compared between Atlantic menhaden with and without ulcerative skin lesions in fall. Atlantic menhaden with ulcerative skin lesions had significantly higher liver somatic indices, neutrophil and monocyte percentages, and splenic mononuclear cell TGF- $\beta$ mRNA levels than did fish without lesions. Hematocrit values, plasma protein, and Ca concentrations were significantly lower in fish with ulcerative skin lesions than in those without. The indicators used in this study at multiple levels of biological organization have provided valuable baseline data for understanding the health status of lesioned and nonlesioned Atlantic menhaden in the Pamlico River.
\end{abstract}

Large fish kills of juvenile Atlantic menhaden Brevoortia tyrannus with ulcerative skin lesions were observed in 1984 in the Pamlico River, North Carolina (Noga and Dykstra 1986). These ulcerative skin lesions were described as focal ulcers that penetrated deep beneath the basement membrane of the affected epithelial cell layers (Noga et al. 1988). Lesions were usually singular with a red margin and were most commonly found on the ventrum of affected fish near the anus (Noga and Dykstra 1986; Levine et al. 1990b). The lesions were termed "ulcerative mycosis" because most contained invasive fungal (oomycete) hyphae of the genera Aphanomyces or Saprolegnia surrounded by

\footnotetext{
* Corresponding author: akjohnson@umes.edu
}

Received March 21, 2006; accepted May 17, 2007 Published online December 31, 2007 severe granulomatous inflammation (Dykstra et al. 1986; Noga and Dykstra 1986).

Apart from the oomycetes, other pathogens have been suggested to play a role in the development of ulcerative lesions in Atlantic menhaden. In the early 1990s, attention focused on the potential association of the dinoflagellate Pfiesteria piscicida with the development of lesions (Burkholder et al. 1992; Noga et al. 1996). The contribution of the oomycete A. invadans to the development of lesions has been validated (Blazer et al. 2002), and the potential contribution of the myxosporean Kudoa clupeidae to the development of some Atlantic menhaden lesions has also been suggested (Reimschuessel et al. 2003). Although these efforts have improved our understanding of the development of ulcerative lesions in Atlantic menhaden, little information is available that describes the health status of free-ranging Atlantic menhaden with 


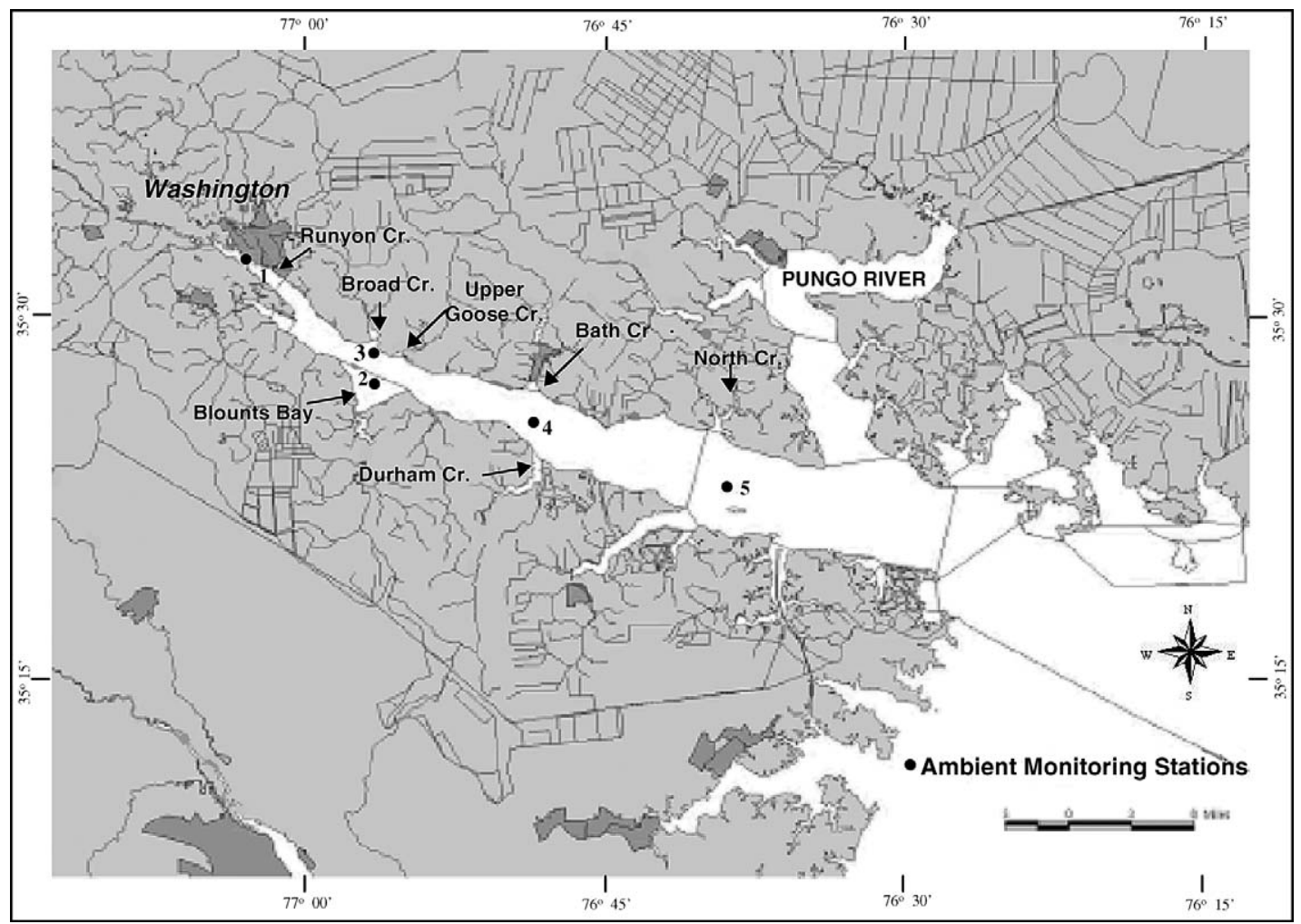

FIgure 1.-Map of the Pamlico River, North Carolina, showing creeks from which Atlantic menhaden were collected in the fall of 2001 and 2002 .

ulcerative lesions and the underlying factors that may make these fish more susceptible to such diseases.

During the fall of 2001 and 2002, Atlantic menhaden with and without ulcerative skin lesions were collected from several creeks in the Pamlico River. An integrated bioindicator approach was used to compare health indices of fish exhibiting gross ulcerative lesions with health indices of fish that lacked lesions; comparisons were made between and within years. This was accomplished by measuring a multitiered suite of health indicators and water quality parameters.

\section{Methods}

A three-tiered suite of bioindicators at the tissue, cellular, and molecular levels was used to compare the health of Atlantic menhaden with and without ulcerative lesions in the Pamlico River during fall. Histopathology and two organosomatic indices (tier I) were used to assess general health status. Hematology, plasma chemistry, and electrolytes provided an assessment of the biochemical status of collected fish (tier II), and an assay for transforming growth factor- $\beta$ (TGF- $\beta$ ) messenger RNA (mRNA) provided an assessment of Atlantic menhaden immune function (tier III).

Field collection.-Juvenile Atlantic menhaden with and without ulcerative skin lesions were caught by cast net from October to November 2001 and from September to October 2002 in several creeks within the Pamlico River system (Figure 1; Table 1). Although fish were sampled earlier in both years, fish with lesions were only found beginning in October 2001 and September 2002; therefore, only fall data were used for comparisons between fish with and without ulcerative skin lesions. In 2001, fish were collected from Blounts Bay and Broad, Upper Goose, Runyon, and North creeks. In 2002, fish were sampled at the same sites as 2001, but fish were only caught in Durham, Broad, and Upper Goose creeks (Figure 1; Table 1). Since Atlantic menhaden are very mobile and a fish's site of capture is not necessarily the same site where it developed the lesions, all sites were pooled and comparisons were made between fish with and without ulcerative skin lesions within and between the 2 years. Surface water quality measurements (at 1-m depth) of dissolved oxygen, temperature, salinity, and 
pH were taken at each sample site. Fish were captured at a similar depth. Sampling was terminated when fish could no longer be obtained (early November 2001 and late October 2002).

Sample processing.-Blood samples were collected from Atlantic menhaden at each study site for the following assays: hematocrit, plasma protein, differential leukocyte counts, and plasma chemistry (2002 only). At each site, blood samples were collected immediately from each fish after capture for the following assays: hematocrit, differential leukocyte counts, and plasma chemistry. Fish were anesthetized with tricaine methanesulfonate (MS-222; Argent Chemical Laboratories, Redmond, Washington) and bled from the caudal vein into heparinized syringes (1$\mathrm{mL}$ syringe; 22 -gauge needle). To reduce the effects of hormonal changes such as increased cortisol levels, blood samples were collected immediately after handling the fish. Fish were then euthanized with an overdose of MS-222 (250 mg/L). Both individual and pooled whole-blood samples were used for hematocrit, plasma protein, differential leukocyte counts, and plasma chemistry. Two to three fish were pooled to obtain the required quantity of blood necessary for these assays. Blood samples were pooled from fish with similar gross ulcerative skin lesions. Blood samples and fish were placed on ice and taken to the laboratory for further processing. Samples were processed within $24 \mathrm{~h}$.

Fork length (FL), body weight, liver weight, and spleen weight were measured, and the presence of external lesions was noted (Levine et al. 1990a). Fish with grossly visible skin ulcers were defined as "fish with lesions," and fish without grossly visible skin lesions were defined as "fish without lesions." Samples of gill, heart, liver, intestine, gonads, and kidney were collected and fixed in 10\% neutral buffered formalin for histopathology (skin lesion histopathology in this population was characterized in a separate study). Spleens (10-20 spleens/sample) were collected in 2001 from fish with and without ulcerative skin lesions for TGF- $\beta$ quantitative real-time polymerase chain reaction (PCR). Spleens were excised from Atlantic menhaden with and without ulcerative lesions $(n=$ 11 samples from both groups), weighed, stored at $4{ }^{\circ} \mathrm{C}$ in sterile cell culture medium (RPMI-1640 plus $10 \%$ heat-inactivated fetal bovine serum, 100 units of penicillin/mL, $100 \mu \mathrm{g}$ of streptomycin/mL, and 2-mM EDTA), and processed within $24 \mathrm{~h}$. Studies in our laboratory have found no significant differences in quantitative analysis between immediate spleen processing and that conducted up to $24 \mathrm{~h}$ after collection (data not included).
Organosomatic indices.-Liver somatic indices (LSIs) were determined for Atlantic menhaden with lesions (2001: $n=20 ; 2002: n=18$ ) and without lesions (2001: $n=30 ; 2001: n=31$, Table 1). Splenosomatic indices (SSIs) were only determined for fish caught in $2002(n=34$ with lesions and 41 without lesions; Table 1). Liver somatic indices and SSIs were calculated as $100 \times$ (organ weight/body weight).

Histopathology.-Histopathology was performed on 51 fish in 2001 (21 fish with ulcerative lesions and 30 fish without lesions) and 50 fish in 2002 (18 with ulcerative lesions and 32 without lesions; Table 1). In 2001, only gill and liver samples were collected for histopathology; in 2002, samples of gill, heart, liver, intestine, gonads, spleen, and kidney were collected. Tissue samples were fixed in $10 \%$ neutral buffered formalin, routinely processed, sectioned at $5 \mu \mathrm{m}$, and stained with hematoxylin and eosin. Tissue sections were examined by light microscopy by a single pathologist who was blinded to skin lesion status; sections were evaluated with the following grading scheme: $0=$ no remarkable microscopic abnormalities, $1=$ very mild changes, $2=$ mild changes, $3=$ moderate changes, $4=$ moderately severe changes, and $5=$ severe changes (at the extreme range of pathology for the given lesion; Hurty et al. 2002). Tissue samples of ulcerative skin lesions were also collected in both years. Ulcerative skin lesions were mainly found on the ventrum of the fish and were classified as early (types I and II), advanced (Figure 2), and healed (Noga et al. 1988). The type I skin lesion is small ( $\leq 5-\mathrm{mm}$ diameter), flat, and red around the area, while the type II lesion (15-20-mm diameter) is raised with a distinct red ring around the margin. These focal ulcers with necrotic tissue often penetrate deep into the peritoneal cavity and adjacent organs in the advanced stage ( $\geq 25-\mathrm{mm}$ diameter). The necrotic mass of tissue is sloughed, leaving a crater-shaped ulcer in the end-stage lesion, while the healed lesion $(<5$-mm diameter $)$ has a notch on the ventrum of the fish near the anus where the tissue has been lost.

Hematology and plasma chemistry._Blood smears for differential leukocyte counts and whole-blood samples were analyzed by the Clinical Pathology Laboratory at the North Carolina State University College of Veterinary Medicine. Blood smears were stained with Wright-Giemsa stain (Volu-Sol, Inc., Salt Lake City, Utah), and 100 leukocytes on each slide were identified. The packed cell volume (PCV) or hematocrit values were determined by reading the packed cell percentages in microhematocrit tubes. Plasma total solids were measured with a refractometer (Leica Microsystems, Wetzlar, Germany). The following substances were measured with a Hitachi 912 
TABLE 1.-Time of sampling, location, water quality measurements, and number of Atlantic menhaden collected for health indices in the Pamlico River system, North Carolina, during fall 2001 and 2002. Fish with and without ulcerative skin lesions were found at all sites except Broad Creek in 2001 (lesioned only) and Durham Creek in 2002 (nonlesioned only). Abbreviations are liver somatic index (LSI); splenosomatic index (SSI); number of lesioned samples $(L)$; and number of nonlesioned samples (NL).

\begin{tabular}{|c|c|c|c|c|c|c|c|c|c|c|c|}
\hline \multirow{2}{*}{$\begin{array}{l}\text { Sampling } \\
\text { date }\end{array}$} & \multirow[b]{2}{*}{ Sites } & \multirow{2}{*}{$\begin{array}{l}\text { Dissolved } \\
\text { oxygen } \\
\text { (mg/L) }\end{array}$} & \multirow{2}{*}{$\begin{array}{c}\text { Temperature } \\
\left({ }^{\circ} \mathrm{C}\right)\end{array}$} & \multirow{2}{*}{$\begin{array}{l}\text { Salinity } \\
(\% 0)\end{array}$} & \multirow[b]{2}{*}{$\mathrm{pH}$} & \multicolumn{2}{|c|}{$\begin{array}{c}\text { Hematocrit } \\
\text { plasma protein }\end{array}$} & \multicolumn{2}{|c|}{ LSI } & \multicolumn{2}{|c|}{ SSI } \\
\hline & & & & & & $L$ & NL & $L$ & NL & $L$ & NL \\
\hline \multicolumn{12}{|l|}{2001} \\
\hline 3 Oct & Broad Creek & 4.49 & 21 & 13 & 7.8 & 2 & & 10 & & & \\
\hline 5 Oct & Blounts Bay & 7.4 & 20.5 & 12.5 & 7.7 & 2 & 2 & 5 & 5 & & \\
\hline 8 Oct & Upper Goose Creek & 8 & 21.3 & 11.9 & 7.85 & 2 & 2 & 5 & 5 & & \\
\hline 18 Oct & Runyon Creek & 7.85 & 20.9 & 5.05 & 7.4 & 2 & 2 & & 10 & & \\
\hline $1 \mathrm{Nov}$ & North Creek & 8.11 & 15.91 & 18 & 7.57 & & 4 & & 10 & & \\
\hline Average & & 7.17 & 19.92 & 12.09 & 7.66 & & & & & & \\
\hline Total & & & & & & 8 & 10 & 20 & 30 & & \\
\hline \multicolumn{12}{|l|}{2002} \\
\hline 8 Sep & Durham Creek & 3.13 & 26.39 & 15.55 & 7.09 & & 6 & & 9 & & 10 \\
\hline $18 \mathrm{Sep}$ & Broad Creek & 4.18 & 25.42 & 6.86 & 6.9 & 3 & 3 & 4 & 6 & 4 & 6 \\
\hline $30 \mathrm{Sep}$ & Upper Goose Creek & 6 & 25.07 & 4.32 & 7.18 & 3 & 3 & 4 & 6 & 4 & 6 \\
\hline 17 Oct & Upper Goose Creek & 7.23 & 20.23 & 8.16 & 7.23 & 3 & 3 & 5 & 5 & 21 & 15 \\
\hline 23 Oct & Durham Creek & 8.15 & 17.7 & 7.07 & 7.6 & 3 & 3 & 5 & 5 & 5 & 4 \\
\hline Average & & 5.7 & 22.9 & 8.4 & 7.2 & & & & & & \\
\hline Total & & & & & & 12 & 18 & 18 & 31 & 34 & 41 \\
\hline
\end{tabular}

chemical analyzer (Hitachi, Ltd., Tokyo, Japan): glucose, phosphorus, $\mathrm{Ca}$, total protein, albumin, aspartate aminotransferase (AST; enzyme number 2.6.1.1; IUBMB 1992), creatine kinase (CK; 2.7.3.2), lactate dehydrogenase (1.1.1.27), $\mathrm{Na}^{+}, \mathrm{K}^{+}, \mathrm{Cl}^{-}$, and bicarbonate $\left(\mathrm{HCO}_{3}{ }^{-}\right)$. The analyzer calculated globulin, albumin : globulin ratio, $\mathrm{Na}^{+}: \mathrm{K}^{+}$ratio, and anion gap. Anion gap was determined as $\left(\mathrm{Na}^{+}+\mathrm{K}^{+}\right)-\left(\mathrm{Cl}^{-}+\right.$ $\mathrm{HCO}_{3}^{-}$).

Transforming growth factor- $\beta$ real-time PCR.Splenic mononuclear cell TGF- $\beta$ transcription was

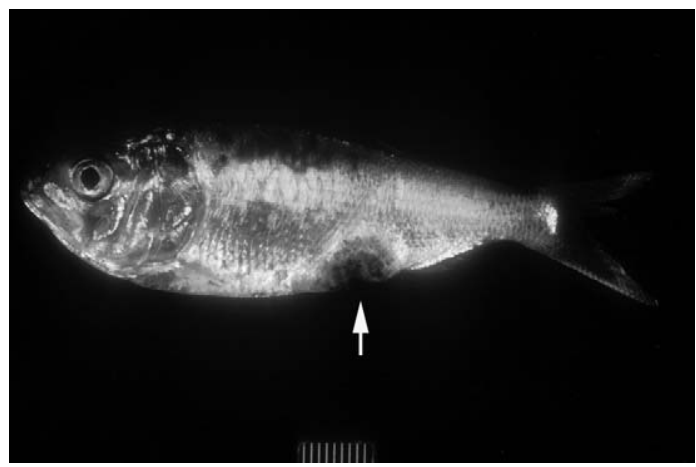

FIGURE 2.-Photograph illustrating an advanced-stage skin lesion in an Atlantic menhaden collected from the Pamlico River during fall 2001. The arrow points to a focally extensive, crateriform skin ulcer $(\sim 1-\mathrm{cm}$ diameter $)$ that is characterized by loss of skin and underlying musculature. The lesion is centered around the anal pore region, the most common site for ulcerative mycosis. determined by quantitative real-time PCR procedures developed specifically for Atlantic menhaden (Johnson et al. 2006). The PCR cycling conditions were optimized for the iCycler (Bio-Rad Laboratories, Inc., Hercules, California), and amplification of reversetranscribed complementary DNA samples and standards was performed in parallel. The PCR and melting procedures were detected in real time with the iCycler instrument. The PCR efficiencies were above $90 \%$, and the correlation coefficient was above 0.996 . Results are reported as the ratio of TGF- $\beta$ : $\beta$-actin derived from copy numbers of plasmid standards.

Statistical analyses.-For each year, data collected from each site were pooled, and values for fish with and without lesions were compared through use of analysis of variance (ANOVA). Comparisons between and within years were performed for hematocrit, differential counts, plasma protein, and LSI. Comparisons were performed with disease and year as main effects and included their interaction. For TGF- $\beta$ collected in 2001 only and plasma chemistry and SSI collected in 2002 only, comparisons were only made between fish with and without lesions collected within the respective years. The Statistical Analysis System was used for all analyses. A visual assessment of residual plots was used to determine homogeneity of variance. To satisfy homogeneity of variance, neutrophil percentages, $\mathrm{K}^{+}$, AST, and $\mathrm{CK}$ were $\log$ transformed, and monocyte percentages were squareroot transformed. Significant ANOVAs $(P<0.05)$ 
TABLE 1.-Extended.

\begin{tabular}{|c|c|c|c|c|}
\hline \multirow{2}{*}{$\begin{array}{l}\text { Sampling } \\
\text { date }\end{array}$} & \multicolumn{2}{|c|}{$\begin{array}{c}\text { Differential } \\
\text { leukocyte counts (plasma } \\
\text { chemistry-2002 only) }\end{array}$} & \multicolumn{2}{|c|}{ Histopathology } \\
\hline & $L$ & NL & $L$ & NL \\
\hline \multicolumn{5}{|l|}{2001} \\
\hline 3 Oct & 10 & & 11 & \\
\hline $5 \mathrm{Oct}$ & 5 & 5 & 5 & 5 \\
\hline 8 Oct & 5 & 5 & 5 & 5 \\
\hline 18 Oct & 5 & 5 & & 10 \\
\hline $\begin{array}{l}1 \mathrm{Nov} \\
\text { Average }\end{array}$ & & 10 & & 10 \\
\hline Total & 25 & 25 & 21 & 30 \\
\hline \multicolumn{5}{|l|}{2002} \\
\hline 8 Sep & & 6 & & 10 \\
\hline $18 \mathrm{Sep}$ & 3 & 3 & 4 & 6 \\
\hline 30 Sep & 3 & 3 & 4 & 6 \\
\hline 17 Oct & 3 & 3 & 5 & 5 \\
\hline $23 \mathrm{Oct}$ & 3 & 3 & 5 & 5 \\
\hline Average & & & & \\
\hline Total & 12 & 18 & 18 & 32 \\
\hline
\end{tabular}

were followed by Tukey's multiple comparison tests (Neter et al. 1996). Data are presented as mean \pm SD.

\section{Results}

\section{Lesion Prevalence}

There were no significant differences in FL between Atlantic menhaden with lesions (2001: $86.75 \pm 4.40$ $\mathrm{mm}$; 2002: $91.39 \pm 4.60 \mathrm{~mm}$ ) and without lesions (2001: $91.67 \pm 10.90 \mathrm{~mm}$; 2002: $99.81 \pm 7.87 \mathrm{~mm}$ ). Body weight also did not differ between fish with lesions (2001: $9.2 \pm 1.6 \mathrm{~g}$; 2002: $10.46 \pm 1.74 \mathrm{~g}$ ) and those without lesions (2001: $11.3 \pm 4.50 \mathrm{~g} ; 2002$ : $13.95 \pm 3.88 \mathrm{~g})$. Although water quality variables differed among collection sites (Table 1), there were no clear patterns that would explain the ulcerative lesions found in Atlantic menhaden. In October 2001, Atlantic menhaden were collected during several fish kill events, and the prevalence of fish with lesions was greater than $50 \%$ for all sites except Runyon and North creeks. Collections during fall 2002 were not associated with any major fish kills, but Atlantic menhaden with and without gross ulcerative lesions were found in all creeks sampled during that period. Lesion prevalence was less than $50 \%$ for all creeks in 2002. Fish collected in 2001 and 2002 had varying stages of ulcerative lesions (from early to late), but advancedstage lesions (Figure 2) were more prominent in 2001 collections than in 2002 collections. Advanced-stage lesions were found in over $80 \%$ of lesioned fish in 2001 and in approximately 50\% of lesioned fish in
2002. Fish with healed lesions accounted for less than $1 \%$ of those caught.

\section{Liver Somatic Index}

In 2001, LSIs were not significantly different between fish with lesions $(5.27 \pm 2.2 ; n=20)$ and those without lesions $(5.36 \pm 1.7 ; n=30 ; P<0.05)$. In 2002, LSIs were significantly higher for fish with ulcerative lesions $(8.82 \pm 2.03 ; n=18)$ than for fish without lesions $(6.85 \pm 1.72 ; n=31 ; P=0.0036)$. There were significant differences in the LSI between years for both lesioned $(P<0.0001)$ and nonlesioned $(P=0.0129)$ fish.

\section{Splenosomatic Index}

Splenosomatic indices were calculated for individual Atlantic menhaden collected in 2002. The SSI was higher for fish with lesions $(0.86 \pm 0.32 ; n=34)$ than for those without lesions $(0.74 \pm 0.31 ; n=41)$, but values were not significantly different $(P>0.05)$.

\section{Histopathology}

2001.-During fall 2001, 51 fish were collected for histopathology. There were 21 fish with ulcerative skin lesions and 30 fish without such lesions. Three fish with gill lesions were collected. One fish with ulcerative lesions had a moderate infiltration of eosinophilic granulocytes, another fish that had ulcerative lesions had moderate chronic branchitis, and a third fish without ulcerative lesions had moderate numbers of gill protozoal parasites but little to no associated inflammatory reaction.

Hepatocellular vacuolation, hepatic congestion, and lymphocyte aggregates were the three types of lesion present in the livers. Both hepatocellular vacuolation and lymphocyte aggregates were found in Atlantic menhaden with and without ulcerative skin lesions. Six fish had mild to moderate diffuse, clear vacuolation of hepatocytes. Fish with ulcerative skin lesions $(n=4)$ had moderate vacuolation, and fish without skin lesions $(n=2)$ had mild vacuolation. Three fish had scattered lymphocyte aggregates (one with skin lesions and two without lesions). Hepatic congestion was only found in fish with skin lesions. These fish $(n=5)$ had mild to moderate focal to multifocal areas of hepatic congestion.

2002.-During fall 2002, 50 fish were collected for histopathology: 18 with ulcerative skin lesions and 32 without lesions. There were no remarkable consistent microscopic lesions in the collected tissues that would distinguish Atlantic menhaden with ulcerative lesions from those without lesions. No lesions were found in the intestines and gonads collected. Microscopic changes in the gills were noted for five fish. Four fish 
TABLE 2.-Comparison of hematology values between Atlantic menhaden (with and without ulcerative skin lesions) sampled in the Pamlico River system during fall 2001 and 2002 ( $n=$ number of pooled samples; $P=$ significance of within-year differences; $\mathrm{ns}=$ not significant). Between-year differences are indicated with asterisks $(* P=0.0454 ; * * P=0.0001 ; * * * P=$ 0.0009).

\begin{tabular}{|c|c|c|c|c|c|c|c|c|c|c|c|c|c|c|}
\hline \multirow[b]{3}{*}{ Value } & \multicolumn{7}{|c|}{2001} & \multicolumn{7}{|c|}{2002} \\
\hline & \multicolumn{3}{|c|}{ Lesioned } & \multicolumn{4}{|c|}{ Nonlesioned } & \multicolumn{3}{|c|}{ Lesioned } & \multicolumn{4}{|c|}{ Nonlesioned } \\
\hline & Mean & $\mathrm{SD}$ & $n$ & Mean & $\mathrm{SD}$ & $n$ & $P$ & Mean & SD & $n$ & Mean & $\mathrm{SD}$ & $n$ & $P$ \\
\hline Neutrophils (\%) & $20.46^{*}$ & 16.7 & 25 & 4.53 & 5.3 & 25 & $<0.0001$ & $8.83^{*}$ & 4.26 & 12 & 4.82 & 4.3 & 18 & 0.0224 \\
\hline Monocytes (\%) & 13.35 & 10 & 25 & 2.61 & 2.06 & 25 & $<0.0001$ & 13.2 & 10.79 & 12 & 2.79 & 1.88 & 18 & 0.001 \\
\hline Lymphocytes (\%) & 28.76 & 16.08 & 25 & $50.72 * *$ & 15.73 & 25 & $<0.0001$ & 31.58 & 12.15 & 12 & $32.56 * *$ & 12.56 & 18 & ns \\
\hline Thrombocytes (\%) & 32 & 20.43 & 25 & $40.6^{* * *}$ & 17.49 & 25 & ns & 43 & 16.49 & 12 & $58.89 * * *$ & 11.1 & 18 & 0.0153 \\
\hline Hematocrit $(\%)$ & 24.75 & 5.6 & 8 & 42.4 & 3.75 & 10 & $<0.0001$ & 30.25 & 12.15 & 12 & 45.83 & 6.2 & 18 & $<0.0001$ \\
\hline Plasma protein $(\mathrm{g} / \mathrm{dL})$ & 2.4 & 0 & 8 & 2.66 & 0.27 & 10 & 0.0249 & 2.43 & 0.09 & 12 & 2.83 & 0.32 & 18 & $<0.0001$ \\
\hline
\end{tabular}

without skin lesions had moderate lamellar thickening, and one fish with skin lesions had a mild protozoal parasite infection. Lesions observed in liver tissue included lymphocyte aggregates, hepatocellular vacuolation, and granulomas. Granulomas were found in one fish without ulcerative lesions. Mild to moderate vacuolation was found in seven fish-three with skin lesions and four without lesions. Six fish had mild lymphocyte aggregates (four with skin lesions and two without lesions). One fish without skin lesions had severe parasitic granulomas in the liver.

Pigmented macrophage aggregates (PMAs) were the most common histological changes found in the kidneys of Atlantic menhaden with $(n=4)$ and without $(n=7)$ ulcerative lesions. One fish with skin lesions had severe neutrophilic inflammation of the hematopoietic tissue, and one fish without skin lesions had moderate granulomas. Ichthyophonus sp. was found in the kidneys. One fish with skin lesions and three fish without skin lesions had spores of Ichthyophonus sp. Both the renal tubules and hematopoietic tissue were expanded and replaced by these spores. The spores were visible grossly as clear spheres found in association with the kidney.

Almost every spleen had PMAs. Fourteen fish with skin lesions (approximately 80\%) and 22 fish without skin lesions (approximately 70\%) had mild to moderate PMAs. The spleen of one fish without skin lesions had moderate parasitic granulomas and another had splenic congestion. A mild trematode (class Trematoda) infestation was observed in one fish with ulcerative lesions.

\section{Hematology}

In 2001, Atlantic menhaden caught with ulcerative lesions had significantly higher neutrophil and monocyte percentages $(P<0.0001)$ and significantly lower lymphocyte $(P<0.0001)$, PCV $(P<0.0001)$, and total plasma protein values $(P=0.0249$; Table 2$)$ than those without lesions. Fish with lesions had lower thrombocyte counts than fish without lesions, but percentages were not significant.

Similar to 2001, both neutrophil and monocyte percentages in 2002 were significantly higher in Atlantic menhaden with lesions $(P=0.0224$ and $P=$ 0.001 respectively; Table 2) than those without lesions. Packed cell volume and plasma protein values were also significantly lower in fish with lesions $(P<$ 0.0001; Table 2) than in fish without lesions. However, unlike 2001, there were no significant differences in lymphocyte percentages in 2002 between fish with and without lesions, and thrombocyte percentages were significantly lower in fish with lesions $(P=0.0153)$ than in those without.

Significant differences in neutrophil, lymphocyte, and thrombocyte percentages were observed between 2001 and 2002 (Table 2). Neutrophil percentage was significantly higher for lesioned fish collected in 2001 $(20.46 \pm 16.70)$ than for those collected in 2002 (8.83 $\pm 4.26 ; P=0.0454$ ) but was not significantly different between years for nonlesioned fish (Table 2). Lymphocyte percentage in nonlesioned fish was significantly higher in $2001(50.72 \pm 15.73)$ than in 2002 (32.56 $\pm 12.56 ; P=0.0001)$, while thrombocyte percentage in nonlesioned fish was significantly lower in $2001(40.6 \pm 17.49)$ than in 2002 (58.89 \pm 11.1 ; $P=0.0009$ ). Monocyte, hematocrit, and plasma protein values were not significantly different between the 2 years (Table 2).

\section{Plasma Chemistry}

Plasma electrolytes were the only plasma chemistries analyzed from samples collected in 2001. These were not included in the comparisons because they were limited to two locations and only nonlesioned fish; therefore, comparisons were only performed for samples collected in 2002.

Atlantic menhaden with lesions had significantly 
TABLE 3.-Plasma chemistry reference values for nonlesioned Atlantic menhaden $(n=18)$, collected in the Pamlico River system during fall 2001 and 2002.

\begin{tabular}{|c|c|c|}
\hline Variable & Mean & SD \\
\hline Glucose (mg/dL) & 33.3 & 6.5 \\
\hline $\mathrm{P}(\mathrm{mg} / \mathrm{dL})$ & 12.4 & 2.0 \\
\hline $\mathrm{Ca}(\mathrm{mg} / \mathrm{dL})$ & 12.0 & 1.4 \\
\hline Total protein $(\mathrm{g} / \mathrm{dL})$ & 2.1 & 0.6 \\
\hline Albumin $(\mathrm{g} / \mathrm{dL})$ & 0.8 & 0.2 \\
\hline Globulin (g/dL) & 1.4 & 0.4 \\
\hline Albumin:globulin & 0.6 & 0.3 \\
\hline Aspartate aminotransferase (units/L) & 267.6 & 67.6 \\
\hline Creatine kinase (units/L) & $5,977.2$ & $2,295.3$ \\
\hline Lactate dehydrogenase (units/L) & $2,433.6$ & 750.3 \\
\hline $\mathrm{Na}^{+}(\mathrm{mmol} / \mathrm{L})$ & 160.3 & 6.4 \\
\hline $\mathrm{K}^{+}(\mathrm{mmol} / \mathrm{L})$ & 6.2 & 2.2 \\
\hline $\mathrm{Cl}^{-}(\mathrm{mmol} / \mathrm{L})$ & 137.4 & 4.8 \\
\hline $\mathrm{HCO}_{3}{ }^{-}(\mathrm{mmol} / \mathrm{L})$ & 6.0 & 1.8 \\
\hline Anion gap & 23.4 & 4.0 \\
\hline $\mathrm{Na}^{+}: \mathrm{K}^{+}$ & 29.2 & 10.7 \\
\hline
\end{tabular}

lower concentrations of $\mathrm{Ca}(9.4 \pm 2.2 \mathrm{mg} / \mathrm{dL})$, total protein $(1.2 \pm 0.7 \mathrm{~g} / \mathrm{dL})$, albumin $(0.5 \pm 0.3 \mathrm{~g} / \mathrm{dL})$, and globulin $(0.8 \pm 0.5 \mathrm{~g} / \mathrm{dL} ; n=12)$ than nonlesioned fish $(\mathrm{Ca}: 12.0 \pm 1.4 \mathrm{mg} / \mathrm{dL}, P=0.0002$; protein: $2.1 \pm$ $0.6 \mathrm{~g} / \mathrm{dL}, P=0.0004$; albumin: $0.8 \pm 0.2 \mathrm{~g} / \mathrm{dL}, P=$ 0.001 ; globulin: $1.4 \pm 0.4 \mathrm{~g} / \mathrm{dL}, P<0.0001 ; n=18$ ). No other plasma chemistry measures differed between fish with and without lesions. Plasma chemistry reference values for nonlesioned Atlantic menhaden are summarized in Table 3.

\section{Transforming Growth Factor- $\beta$}

Splenic mononuclear cell TGF- $\beta$ mRNA production was significantly higher in Atlantic menhaden with lesions (TGF- $\beta$ : $\beta$-actin ratio $=325.0 \pm 146.1$ ) than in those without (155.5 $\pm 111.0 ; P=0.0061$; Figure 3$)$.

\section{Discussion}

Due to the complexity of aquatic ecosystems, causal associations can be extremely difficult to establish for potential risk factors in field-based studies, even when a particular disease has a relatively high spatial and temporal prevalence. This has proven especially difficult with ulcerative mycosis in Atlantic menhaden, even with many years of study by many groups. Studies in the 1980s found ulcerative lesions in Atlantic menhaden to be associated with low salinity (Dykstra et al. 1986; Levine et al. 1990b) and that low salinity favored growth of Aphanomyces (Dykstra et al. 1986). Also, abrupt salinity changes have been reported to cause significant decreases in serum electrolytes and osmotic pressure in Atlantic menhaden. Atlantic menhaden serum $\mathrm{Na}^{+}$and $\mathrm{Cl}^{-}$concentrations obtained from pooled blood samples decreased significantly after abrupt transfer from high (35.0\%o) to

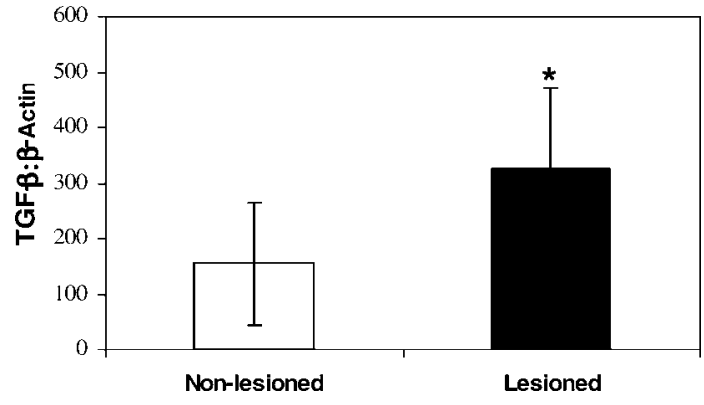

FIGURE 3.-Comparison of transforming growth factor- $\beta$ (TGF- $\beta$ ) : $\beta$-actin ratio (mean \pm SD) between Pamlico River Atlantic menhaden with ulcerative skin lesions (black bar) and those without skin lesions (white bar) in fall 2001 ( $n=11$ fish/ group). Absolute values (copies of TGF- $\beta$ normalized to copies of $\beta$-actin) were significantly higher for lesioned fish (asterisk) than for nonlesioned fish $(P=0.0061)$.

low salinity (3.5\%o; Engel et al. 1987). Atlantic menhaden occur in low-salinity waters without developing ulcerative lesions (Dykstra et al. 1986); therefore, other environmental factors must also be involved. Because the Pamlico River system has been the focus of so many fish kills and lesion events, a baseline of clinicopathological data on this disease in Atlantic menhaden is badly needed. We sought to determine the differences between lesioned and nonlesioned Atlantic menhaden through use of a threetiered suite of health indicators.

Tier I indicators (LSI, SSI, and histopathology) were used to assess the general health of lesioned and nonlesioned Atlantic menhaden. The differences in LSI between years may reflect fish health and nutritional state and the local availability of specific dietary constituents. Alternatively, the higher LSIs in lesioned fish caught in 2002 may reflect hyperplasia or hypertrophy of the hepatocytes and may be an adaptive response to increase the liver's capacity to detoxify unknown contaminants (Heath 1995). Although these associations have yet to be made in the Pamlico River system, bioindicators like the LSI may help direct further investigations into possible chemical contaminants in the river.

Histopathology performed on the major internal organs showed that Atlantic menhaden in the Pamlico River did not have any major predisposing systemic disease conditions that would lead to ulcerative skin lesions. Examination of gill, liver, spleen, kidney, intestinal tract, and gonad sections did not distinguish between fish with and without ulcerative skin lesions. With the exception of hepatic congestion found in lesioned fish (5 of 21) caught in 2001, morphological changes did not appear to be associated with the 
presence of ulcerative skin lesions. Hepatic congestion, or the pooling of blood within liver sinusoids, can be caused by cardiac insufficiency or by factors that prevent normal outflow of the hepatic circulation, such as enlargement of hepatic cords or an increase in overall hepatic mass. This is most likely a result of liver enzyme induction by xenobiotics (Heath 1995). Histopathology was not sensitive enough to detect changes in the hematopoietic tissues that might signal immunocompromise, but inflammatory changes were reflected in the hemogram. This underscores the need for a suite of bioindicators at multiple levels of specificity or biological organization.

Tier II health indices (hematology and plasma chemistry) demonstrated significant differences between lesioned and nonlesioned fish. Relative neutrophilia, monocytosis, thrombocytopenia, and lymphocytopenia in Atlantic menhaden with lesions have also been reported in many other teleosts during stressful events and disease outbreaks (Ellsaesser and Clem 1986; Pickering and Pottinger 1988). Lymphocytopenia, monocytosis, and neutrophilia suggest a systemic, nonspecific immune response and were also observed in our laboratory studies with Atlantic menhaden injected with the synthetic glucocorticoid, triamcinolone (Johnson et al. 2006). Cortisone and adrenocorticotropic hormone caused lymphocytopenia and thrombocytopenia in rainbow trout Oncorhynchus mykiss (Blaxhall 1972). Decreased thrombocyte and lymphocyte counts have also been observed in brown trout Salmo trutta and rainbow trout that were chronically stressed by crowding (Pickering and Pottinger 1987). These changes in circulating leukocyte levels are consistent with suppression of the immune system and increased susceptibility to disease mediated by the hypothalamic-pituitary-interrenal axis.

Low hematocrit values may be associated with blood loss or concurrent leukopenia or disease. Low hematocrit values observed in Atlantic menhaden with ulcerative skin lesions have also been reported in bacterially infected rainbow trout (Barham et al. 1980), gilthead seabream Sparus aurata subjected to a simulated disturbance stress (Pages et al. 1995), and rainbow trout exposed to copper effluent (Dethloff et al. 2001). The decrease in hematocrit indicates a decrease in oxygen carrying capacity (Heath 1995), and the loss of blood and inflammation from the open skin lesions in Atlantic menhaden may be partially responsible. Thus, the low hematocrit values and thrombocytopenia coupled with the decreased total protein, albumin, and globulin provide evidence of blood loss from the ulcerative skin lesions.

Differences in hypoproteinemia, hypoalbuminemia, and hypoglobulinemia between Atlantic menhaden with lesions and those without lesions might also reflect hemodilution, a decrease in hepatic production as a result of hepatic dysfunction, disease, or both. Hemodilution from osmotic changes across skin ulcers in hypo-osmotic water (less than about $9 \mathrm{~g} / \mathrm{L}$ ) could contribute to lower PCV and protein values, but in hyperosmotic water (more than about $9 \mathrm{~g} / \mathrm{L}$ ), skin ulcers would contribute to hemoconcentration (indicated by higher PCV and protein or less-severe decreases in cases of blood loss). Anemia caused by hemodilution has been observed in Chinook salmon $O$. tshawytscha infected with the diplomonad parasite Spironucleus barkhanus (Guo and Woo 2004), whereas a decrease in plasma protein resulting from the absorption of excess water has been suggested to occur in Koi Cyprinus carpio carpio with skin ulcers (Tripathi et al. 2005). The low concentrations of total plasma protein, albumin, and globulin have also been detected in other diseased fish (Barham et al. 1980). Since most of the Ca present in plasma is bound to albumin, the significantly lower Ca concentrations in lesioned fish are expected. Low total plasma protein has been shown to reflect infectious disease, kidney damage, and nutritional imbalance (Wedemeyer et al. 1984). The decrease in plasma proteins could also result from (1) a protein catabolism increase due to cachexia (Mazeaud et al. 1977) or (2) protein degradation associated with immunological responses (Pages et al. 1995).

The lack of significant differences in muscle enzymes and other hematological parameters observed between fish with and without lesions suggests that these analytes are not sensitive indicators of the observed gross pathology. Alternatively, some fish without grossly visible lesions may be in an earlier stage of disease development.

Splenic mononuclear cell TGF- $\beta$ : $\beta$-actin mRNA ratios were significantly elevated in Atlantic menhaden with lesions relative to those without lesions. Transforming growth factor- $\beta$ is a cytokine that plays a central role in immunoregulation. Its immunomodulatory effects are primarily suppressive, although it has some proinflammatory effects. It downregulates $\mathrm{T}$ - and B-cell proliferation, macrophage activation, and macrophage respiratory burst (Ruscetti and Palladino 1991). The elevated production of TGF- $\beta$ observed in Atlantic menhaden with gross ulcerative lesions, when taken in context with the other health parameters, is indicative of a suppression of the immune system. Increased production of TGF- $\beta$ is important in the suppression of activated inflammatory cells, which is essential in the resolution of an inflammatory response (McCartney-Francis and Wahl 1994). Therefore, it is likely that Atlantic menhaden with lesions do possess 
an active systemic inflammatory response and are capable of regulating that response to prevent further tissue damage and promote healing.

Since the 1980s, researchers have been investigating the link between ulcerative lesions in Atlantic menhaden and the influence of many factors, both endogenous and exogenous. The approach of using multiple health indicators at three different levels of biological organization is aimed at better understanding the health status of Atlantic menhaden in the Pamlico River during the development of ulcerative skin lesions. Atlantic menhaden with ulcerative skin lesions had significantly higher LSIs, neutrophil and monocyte counts, and splenic mononuclear cell TGF- $\beta$ mRNA levels and significantly lower lymphocyte counts, thrombocyte counts, hematocrit values, plasma proteins, and Ca than those without ulcerative skin lesions. These health indicators have identified differences in Atlantic menhaden with and without ulcerative skin lesions, thus increasing our knowledge of changes in the health of these fish in the Pamlico River. However, to fully understand the factors that contribute to the incidence of ulcerative lesions in an estuary, the exposure history of healthy or nonlesioned fish at the beginning of the observation period must be followed over time. Effective methods for conducting sentinel studies in cages and for marking and monitoring the movement of Atlantic menhaden in the estuary (e.g., telemetry) should be explored to help investigators more clearly define the factors associated with development of ulcerative skin lesions and other disease problems.

\section{Acknowledgments}

We thank the Pamlico Rapid Response Team (Division of Water Quality, North Carolina Department of Environment and Natural Resources [NCDENR]) for help with field collections. Funding for this study was provided in part by the NCDENR (Project Number EW 200020) and North Carolina Department of Health and Human Services-Centers for Disease Control funds (Project Number 01081-01).

\section{References}

Barham, W. T., G. L. Smit, and H. J. Schoonbee. 1980. The haematological assessment of bacterial infection in rainbow trout, Salmo gairdneri Richardson. Journal of Fish Biology 17:275-281.

Blaxhall, P. C. 1972. The haematological assessment of the health of freshwater fish: a review of selected literature. Journal of Fish Biology 4:593-604.

Blazer, V. S., J. H. Lilley, W. B. Schill, Y. Kiryu, C. L. Densmore, V. Panyawachira, and S. Chinabut. 2002. Aphanomyces invadans in Atlantic menhaden along the
East Coast of the United States. Journal of Aquatic Animal Health 14:1-10.

Burkholder, J. M., E. J. Noga, C. W. Hobbs, H. B. Glasgow, Jr., and S. Smith. 1992. A new 'phantom' dinoflagellate is the causative agent of major estuarine fish kills. Nature 358:407-410.

Dethloff, G. M., H. C. Bailey, and K. J. Maier. 2001. Effects of dissolved copper on select hematological, biochemical, and immunological parameters of wild rainbow trout (Oncorhynchus mykiss). Archives of Environmental Contamination and Toxicology 40:371-380.

Dykstra, M. J., E. J. Noga, J. F. Levine, D. W. Moye, and J. H. Hawkins. 1986. Characterization of the Aphanomyces species involved with ulcerative mycosis (UM) in menhaden. Mycologia 78:664-672.

Ellsaesser, C. F., and L. W. Clem. 1986. Haematological and immunological changes in channel catfish stressed by handling and transport. Journal of Fish Biology 28:511521.

Engel, D. W., W. F. Hettler, L. Coston-Clements, and D. E. Hoss. 1987. The effect of abrupt salinity changes on the osmoregulatory abilities of the Atlantic menhaden Brevoortia tyrannus. Comparative Biochemistry and Physiology 86A:723-727.

Guo, F. C., and P. T. K. Woo. 2004. Experimental infections of Atlantic salmon Salmo salar with Spironucleus barkhanus. Diseases of Aquatic Organisms 61:59-66.

Heath, A. G. 1995. Water pollution and fish physiology. Lewis Publishers, Boca Raton, Florida.

Hurty, C. A., D. C. Brazik, J. M. Law, K. Sakamoto, and G. A. Lewbart. 2002. Evaluation of the tissue reactions in the skin and body wall of koi (Cyprinus carpio) to five suture materials. Veterinary Record 151:324-328.

IUBMB (International Union of Biochemistry and Molecular Biology). 1992. Enzyme nomenclature 1992. Academic Press, San Diego, California.

Johnson, A. K., C. A. Harms, J. F. Levine, and J. M. Law. 2006. A quantitative real-time RT-PCR assay to measure TGF- $\beta$ mRNA and its correlation with hematologic, plasma chemistry and organo-somatic indices responses in triamcinolone-treated Atlantic menhaden, Brevoortia tyrannus. Developmental and Comparative Immunology 30:473-484.

Levine, J. F., J. H. Hawkins, M. J. Dykstra, E. J. Noga, D. W. Moye, and R. S. Cone. 1990a. Epidemiology of ulcerative mycosis in Atlantic menhaden in the TarPamlico River, North Carolina. Journal of Aquatic Animal Health 2:162-171.

Levine, J. F., J. H. Hawkins, M. J. Dykstra, E. J. Noga, D. W. Moye, and R. S. Cone. 1990b. Species distribution of ulcerative lesions on finfish in the Tar-Pamlico River, North Carolina. Diseases of Aquatic Organisms 8:1-5.

Mazeaud, M. M., F. Mazeaud, and E. Donaldson. 1977. Primary and secondary effects of stress in fish: some new data with a general review. Transactions of the American Fisheries Society 106:201-212.

McCartney-Francis, N. L., and S. M. Wahl. 1994. Transforming growth factor $\beta$ : a matter of life and death. Journal of Leukocyte Biology 55:401-409.

Neter, J., M. H. Kutner, C. J. Nachtsheim, and W. Wasserman, editors. 1996. Applied linear statistical models. McGraw Hill, Boston. 
Noga, E. J., and M. J. Dykstra. 1986. Oomycete fungi associated with ulcerative mycosis in menhaden, Brevoortia tyrannus (Latrobe). Journal of Fish Diseases 9:47-53.

Noga, E. J., L. Khoo, J. B. Stevens, Z. Fan, and J. M. Burkholder. 1996. Novel toxic dinoflagellate causes epidemic disease in estuarine fish. Marine Pollution Bulletin 32:219-224.

Noga, E. J., J. F. Levine, M. J. Dykstra, and J. H. Hawkins. 1988. Pathology of ulcerative mycosis in Atlantic menhaden Brevoortia tyrannus. Diseases of Aquatic Organisms 4:189-197.

Pages, T., E. Gomez, O. Suner, G. Viscor, and L. Tort. 1995. Effects of daily management stress on haematology and blood rheology of the gilthead seabream. Journal of Fish Biology 46:775-786.

Pickering, A. D., and T. G. Pottinger. 1987. Crowding causes prolonged leucopenia in salmonid fish, despite interrenal acclimation. Journal of Fish Biology 32:701-712.

Pickering, A. D., and T. G. Pottinger. 1988. Lymphocytopenia and the overwinter survival of Atlantic salmon parr, Salmo salar L. Journal of Fish Biology 32:689-697.
Reimschuessel, R., C. M. Gieseker, C. M. Driscoll, A. Baya A. S. Kane, V. S. Blazer, J. J. Evans, M. L. Kent, J. D. W. Moran, and S. L. Poynton. 2003. Myxosporean plasmodial infection associated with ulcerative lesions in young-of-the-year Atlantic menhaden in a tributary of the Chesapeake Bay, and possible links to Kudoa clupeidae. Diseases of Aquatic Organisms 53:143-166.

Ruscetti, F. W., and M. A. Palladino. 1991. Transforming growth factor- $\beta$ and the immune system. Progress in Growth Factor Research 3:159-175.

Tripathi, N. K., K. S. Latimer, C. R. Gregory, B. W. Ritchie, R. E. Wooley, and R. L. Walker. 2005. Development and evaluation of an experimental model of cutaneous columnaris disease in koi Cyprinus carpio. Journal of Veterinary Diagnostic Investigation 17:45-54.

Wedemeyer, G. A., D. J. McLeay, and C. P. Goodyear. 1984. Assessing the tolerance of fish and fish populations to environmental stress: the problems and methods of monitoring. Pages 163-196 in V. Cairns, P. Hodson, and J. Nriagu, editors. Contaminant effects on fisheries. Wiley, New York. 